It has been reproduced from ins hest avaitable copy to permit the hroindest possible availablltity.
UICRL-

PREPRINT

\title{
Hydrothermal Interaction of Topopah Spring \\ Tuff With J-13 Water As A Finction \\ of Temperature
}

\author{
Kevin Knauss \\ Joan Delaily \\ Will iam Beiriger \\ Dennis Peifer
}

This paper was prepared for submittal to:

\author{
Material Research Society Symposium \\ Proceedings \\ Boston, MA Nov. 25-30, 1984
}

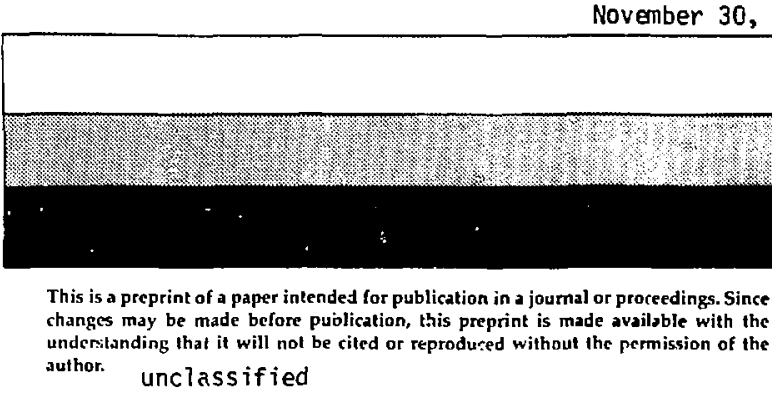
unclassified

\section{DISCLAIMER}

This reporl was prepared as an account of work sponsored by an agency of the United States Government. Neither the United States Government nor any agency thereof, nor any of their employees, makes any wartanty, express or implied, or assumes any legal liability or responsibility for the accuracy, completeness, or usefulness of any in[ormation, apparatus, product, or process disclosed, or represents that its us: would not infringe privately owned rights. Reference herein to any specific commercial product, process, or servioc by trade name, trademark, manufacturer, or otherwise does not necessarily constitute or imply its endorsement, recommendation, or favoring by the United States Government or any agency thereor. The views and opinions of authors expressod herein do not necessarily state or reflect those of the United States Government or any agency thereor. 
KEVIN G. KNAUSS, J. M. DELANY, W. J. BEIRIGER, ANO U. W. PEIFER Earth Sciences Department, Lawrence Livermore Nutional Laboratory, Livermore, CA y4b50

\section{ABSTRACT}

In support of the Nevaua Nuclear Haste Storage Investigations Pruject experiments were conducted to stuay the hydr,thermal interaction of rock and water representative of a potential repository in tutt. These experiments provided data relevant to near-fielu repository conditions that car: ve used to: assess the ability to use "accelerated" tests based on the SA/V (surtace areaivolume) yarameter and temperature; al low the measurement of chemlcal changes in phases preseric in the tuff before reaction as well as the identification and chemical analysis of secondar $y$ phases resulting trom hyurothermal reactions; alla aemonstrate the usefulness of geochemical nivoeling in a repository environmenz using the Eus/6 thermodynamic/kinetic yeochemical modeliny code. Crusheo tuft and polishea waters of :utf were reacted with a natural groind water in uicksun-type gold-cell rucking dutoclaves which were periodically sampleu unaer insitu conoitions. Kesults were compared witn predictions based on the EQ3/0 geochemical nodeling code. Eight shori-term experiments (2 to 3 montns) at $160^{\circ} \mathrm{C}$ ana $\angle 50^{\circ} \mathrm{C}$ nave been completed using tuft from Dotn arilicore and outcrop. Long-term experiments at $90^{\circ} \mathrm{C}$ and $150^{\circ} \mathrm{C}$ using drillcore polished wafers are in progress. This paper will focus on the results of the $150^{\circ} \mathrm{C}$ and $250^{\circ} \mathrm{C}$ experiments using drilicure polishea wafers.

\section{INTKOOULTION}

Under anticipatad conditions the intial response of the near-field environmeric to the neat generated by the emplacement of nuclear waste packayes is an increase in semperatu'e sutficient to ury out the partially-saturated host rock. Foilowing the thermal pulse the rock cools and liguid water re-enters the near-fiela. As the water passes through the heated rock its composition is altereo by interaction at temperatures of $\sim 100^{\circ} \mathrm{C}$. This alterea water interacts witn the waste packages by corroding canisters and orssulving the waste form. To estimate the magnituoe of these reactions, the water composition must oe known. Repositury scale therma! modeling suggests poteritial for the existence of liquid water in pores at up to $140^{\circ} \mathrm{C}$ in cases witn no venting $[1]$, and package scale modeling shows waste centerline temperatures up to $230^{\circ} \mathrm{C}[<]$. These estimates place upper buunos on experimental conditions appropriate for unanticipated ouc possible scerlarios. Testing at these temperatures also aids in developing geochemical modeling computer coaes by accelerating rates of reaction. Tnis paper presents the results of such tests and compares the results to those prejicted by the EQ $3 / 6$ geochemical modeling code $[3]$. 
The rock wafers were cut from drillcore samples taken from potential repository aepth in hole USW $\mathrm{L}-1$ at Yucca Mtn. The rock is a densely weloed, devitrified, vapor-phase alcered, crystal-poor, rhyolitic asnfluw tuff, the Topupan Spring Menber of the Paintbrush Tuff [4]. The wafers were 1.0 in. dia. $x 0.1$ in. thick, hand-polished and ultrasonically cleaned in alstillea water. The water was taken from well $\mathrm{J}-$ is in Jackass Flat east of Yuccd Mtn which produces largely from the Topupan Spring Member. This ground water is being used by the NiWSI Prograil as representative of water from the unsaturated zore and is we!l-characterized $[5]$.

Experiments were run di $150^{\circ} \mathrm{C}$ and $250^{\circ} \mathrm{C}$ for $b 6^{\circ}$ days using ulckson-type yola-ceil rocking autoclaves [6] inoaified to hola rock wafers. Fluiu samples were taken perroulcally for $\mathrm{pH}$, cation (ICH-ES) and anlun (IC) analyses. The Ar BET gas adsorption surface areas illeasured un the rock wafers indicate typical experimental SA/V ratios of 40 cin-1. At the termination of eacll run the rock wafers were removeo as rapialy ds posside and rinsed thoroughly in distilled water, dried and C-coated for SEM ODServation and EMP analysis using Doth EDS and wOS.

\section{OISCUSSION UF ANALYTICAL RESULTS}

The tluidanalyses are plotted versus time in Figures 1 and 2 fur the $150^{\circ} \mathrm{C}$ and $250^{\circ} \mathrm{C}$ experiments, respectively.

In the $1 s U^{\circ} \mathrm{C}$ experiment the $\mathrm{Al}$ concentration increased rapidy at first from the iritial $\mathrm{J}-1 \mathrm{~s}$ value $(0.03 \mathrm{ppm})$ to a maximum of $1.2 \mathrm{ppm}$ but

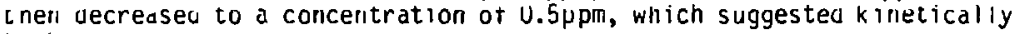
inhiditeo precipitation. The Si cuncertration ificreased exponentially from the $J-1$ s value ( $\ddot{c} 9 \rho \rho n$ ) to a value close to cristodalite saturation ( $12<\mathrm{p} p m$ ) by the end of the run. The Ca concentration decreasea quickly from $12 \mathrm{ppm}$ to $6 \mathrm{ppm}$ and $\mathrm{Mg}$ initially at $1.9 \mathrm{ppm}$ was remuved to low leveis $(<U .1 \mathrm{ppm})$. K reseliblea $A \mid$ and after an initial rise frum 4.6ppin to $6.5 \mathrm{ppm}$ oecreaseo to 4.9ppin. Na showeo a somewhat irregular sluw $r$ ise trum approximately $41 \mathrm{ppm}$ to $45 \mathrm{ppm}$. The quenched $\mathrm{pH}$ aropped to a value of 0.8 ana remairied constant. Other than a decrease in $\mathrm{CU}_{2}$ there was no sigriticant cnange in anion content. The more complex behavior of $\mathrm{Ca}, \mathrm{K}$, ana Al reflect the effects of aissolution of reactants and precipitation of metastavle run products.

The effects of hydrotnermal alteration of the host rock phenocrys at $150^{\circ} \mathrm{C}$ were seen as highlighting of twinning by tl:e formatiun of etch pits on felaspars, and the general corrosiun of biotite. The smaller alkali felaspar crystals furmed by granophyric devitrification of the host rock matrix and from vapor-phase ceposition in lithopnysal cavities appearea lu De particularly prone to hydrotnermal attack as did the other fine-gralned devitrification products making up the matrix. Qualtitative wOS analyses snowed no compositional changes in the phenocrysts or matrix pnases of the nost rock as a result of hyorothermal alteration. 
SLM observation of the surface of the core warer was used to study secondary minerais formeo at $150^{\circ} \mathrm{C}$ (Figure 3 ). Baseo on chemical compositiun oetermined oy LOS analyses and on SEM morphology these are thaugnt to include: illite, Mg-, Ca- \&/or Fe-rich clays, gidosite, calcice ano a pure Si phase (cristodalite?). The "clays"

(illite/montmorillonite) were dominant and the other phases much less abunuant. The total amount of reaction products was quite small.

The solutiun analyses in the $66-d a y 250^{\circ} \mathrm{C}$ experiment (Figure 2) snowed that Al increased rapidiy at first to $3.6 \mathrm{ppm}$, then decreased exponentially to a minimum of $1.6 \mathrm{ppm}$, and findlly began to $r$ ise again towerds the end of the experiment reaching $3 \mathrm{ppm}$. Si increased exponentially to cristobalite saturation (350ppm) taking 2 wks to reach steady-state. Ca was removed quickly to low levels (<lppm) and $\mathrm{Mg}$ was completely removed $(<0$. I p pm). The $K$ generally followed the $A$ l trena as at $150^{\circ} \mathrm{C}$, except that after inltially rising to $6.5 \mathrm{ppm}$ it fell in an erratic manner and reachea concentrations appruximately equal to the starting value. Na snowed a slight decline trum the starting concentration. The quenched $\mathrm{pH}$ dropped to about 6.3 ano remaineo constant. The $\mathrm{CO}_{2}$ decreased while $\mathrm{F}$ and $\mathrm{Cl}$ increased slightly and other anions remained constant. Al, $K$ and $C a$ again displayed the most complex Dehavior.

Hyarutherilal alteration of the cutif at $250^{\circ} \mathrm{C}$ resulted in a securlary mineral asseriblage that was aifferent trum that formed ac $150^{\circ} \mathrm{L}$ (Figure 4). The oominant seconoary mineral produced was the zeolite aacniaraite. Aouncant large prismatic crystals with smaller interpenterant crystals and rosettes of crystals were prouuced. A cluster of crystals hana-picked from the surface of the water was run in a Gandolti $X-r$ ay $c$ amera to make a positive identitication and to meosure a-spacings for calculatiosi of cell constants using a linear regression technique. A polished grain mount of dachiarulte crystals was and yzea oy wDS and these resuits as well as the characterization descrioeu adove nave oeen reported elsewnere $\lfloor 7\rfloor$. In the $250^{\circ} \mathrm{C}$ experiment other seconiary minerals usserved were: mordenite, clay (ilite/montmoriliunite), and a pure Si phase (cristudalite?). Dacmiardite and mordenite were far more abundant than the other phases. The total amount of reaction prooucts was much greater at $250^{\circ} \mathrm{C}$ than at $150^{\circ} \mathrm{C}$.

\section{GEOCHEMILAL YUUELING OF $150^{\circ} \mathrm{C}$ EXPERIMENT}

The rock/water interactions observed oetween the Topopall Spring Tuff and $\mathrm{J}-13$ groundwater at $150^{\circ} \mathrm{C}$ in a closed system were simulated using the Eu3/0 reaction path cude. Water frolı well $j-13$ anlalyzed at aay 3 was used as the initial solution composition. EQ3NR was usea to generate the model aqueous solution. The dissolved aluminum concentration in the moael solution was constraineo ta satisfy the lineral solubility equilioria for kaolinite in order to initially reduce the number of supersacuraten mineral phases in the solutioll. The Topopah Spring Turf was represented oy an assemblage of six minerals; alkali felaspar, plagioclase, cristobalite, quartz, biotite, and montmorillunite based un tne petrologic description given bj Warren et a]. [8]. The surface area of the core wafer (determined Dy BET Ar methoo) and the valume percent of 
eacn phase were used to estimate the specific surface area for the individual minerais. Dissolution rate constants for quartz and cristobalite were calculated at $150^{\circ} \mathrm{C}$ using the data given by Rimstiat and barnes [9]. The rate constants used for the felospars and Diot ite were based on estimates that assume aissolution of the soliu is controlled by surface reactions ( $E_{a c t}=14 \mathrm{kcal}$ for grain size $2100 \mathrm{u}$ $[10 \mathrm{~J})$. The estimated values were then reduced by approximately an order of magnitude to account for the smaller surface area of the wafer and decreased surface reactivity causea by ultrasonic cleaning. A relative $r$ ate constant was used for miontinorillonite that assumed dissolution of thle phase was cumplete within y cays. The code was constrained to suppress all silica minerals less solud le than cristodalite. All douitional phase, maximum microcline was eliminated from phases alluwed to precipitate because the primary feldspar is represented by sanidine.

The EQ3/0 calculations redistically preaict that none of the initial reactants are exhausted and a relatively minor amount of the rock oissolves auring the given run interval. The final concentrations of all majur cations in sulution predicted by the model closely approuch the tinal measurea cation compositions for these elements (Figure 1). As silicd (primarily cristobalite and quartz) dissolves, its concentration is shown to increase to a steady-state value that approaches cristodalite solubility near the latter stages of the experiment. Na, Al, and $\mathrm{Mg}$ show tairiy constant trends over the run interval. The sharp rise in Al concentration can be attriuutea to rapia dissolution at $150^{\circ} \mathrm{C}$ of the sillall amount of niontmorillonite present in the host rock. The initial orop in Ca concentration is oue to the formation of minor calcite. The continued gradual decrease in $\mathrm{Ca}$ throughout the experiment is due to the precipitation of Ca-smectite. The formation of smectite also coincides with a orop in Al concentration in the same interval. The sharp rise in the $k$ concentration during the first few days of the experiment cannot be accounted for by the dissolution of the major potassium phase, sanidine. The only other phase present contalning significant $K$ in the host rock is biotite. The kinetic rate laws available in the current version of EQO provide only for uissolution reactions. Precipitation appears in EQ6 only as an instantaneous process once saturation is reached, although the incorporation of precipitation $r$ ate laws is currently in progress. These results can be used to estimate the rate of precipitation of seconaary phases udserved in the alterea wafers. It is probaly redsonale to assumie tnat the secondary phase representea by the $K-\operatorname{sink}$ will have to ue represented theoretically by a metastade illite or sinectite, because metastable phases typically precipitate quickly from solution, ofterl with variable cation compositions that change as the composition of the solution changes. Althougn these preliminary modeling results can not account for all secondairy phases determined by SEM observation and EOS analysis, tnese results indicate the importance of the careful characterization of secondary mineral assemb lages, and the great need for theoretical representation of metastable phases when modeling low temperature natural systems. Data for the $250^{\circ} \mathrm{C}$ experiment have not beel modeled because no thermodynamic data exists for the dominant mineral (aachiardite) observed in the alteration as semblage. 


\section{CONCLUSIUNS}

These experiments investigate the pore water chemistry in tuff as it is mualfied oy a heat source such as a HLi repository. The alterea water chemistry differs primarily in dissolved silica, which is deterinined oy cristodalite sulubility. The water remains relatively benign with respect to waste package survivability, especially with regard to its anian content and $\mathrm{pH}[\mathrm{ll}]$. The dominant secondary minerals produced (clays and ceolites) have nigh surface areas, high CEC and positive sorption capabilities and thus may help to reduce radionuclide mobility in the near-field. In the far-field silica may precipitate as the alteres water moves down the tnermal gradient away froin the heat source. These experiments showed that increased temperature yields a different metastad le mineral assemblage ano probadly can not be used as a direct relatiun to accelerate rock/water interactions and must be used with caution. In general the mirieral assemblage produced in short time at high temperature resemo les that produced by nature in long time at low temperature, but the fluid compositions in each case are considerably different. The model simulation can closely approxinate the evolving fluid composition but it does not account for all the secondary phases actually observed. The relative success in modeling these experiments with the EQS/o geochemical modeling code suggests that long term prediction of water chemistry is a potentialiy achievable goal.

\section{REFERENCES}

1. ..v. Travis and uthers, Los Alamos National Laboratory Report LA-UR 84-40 (1984).

2. W. Stein and others, Lawrence Livermore National Laboratory Report UC $10-20091$ (1984).

3. T.u. Wolery, Lawrence Livermure National Laboratary Report ULRL-52b58 (197y).

4. K.G. Knauss, Lawrence Livermore National Laburatory Report UCKL-535b8 (1984).

5. W.K. Uaniels and many (29) others, Los Alamos National Lauoratory Report LA-9328-MS (1982).

6. W.E. Seyfried and others, Am. Mineral. 64, 646 (1979).

7. K.G. Knauss ano W.J. Beiriger, Geol. Soc. Am. Prog. Abstr. v.16, n.6, $561(1984)$.

ย. R.G. Warren and others, Los Alamos National Laboratory Report LA- IU003-MS (1984).

9. J.U. Rimstidt ana H.L. Barnes, Geochım. Cosmochim. Acta, 44, 1683 (1980).

10. T.J. Wolery, written communication (1984).

11. R.0. McCright ano others, MRS Symp. Proc., 26,309 (1984).

* "Work performed under the auspices of the U.S. Uepartment of Energy Dy the Lawrence Livermore National Laboratory under contract number W-7405-ENG-48." 

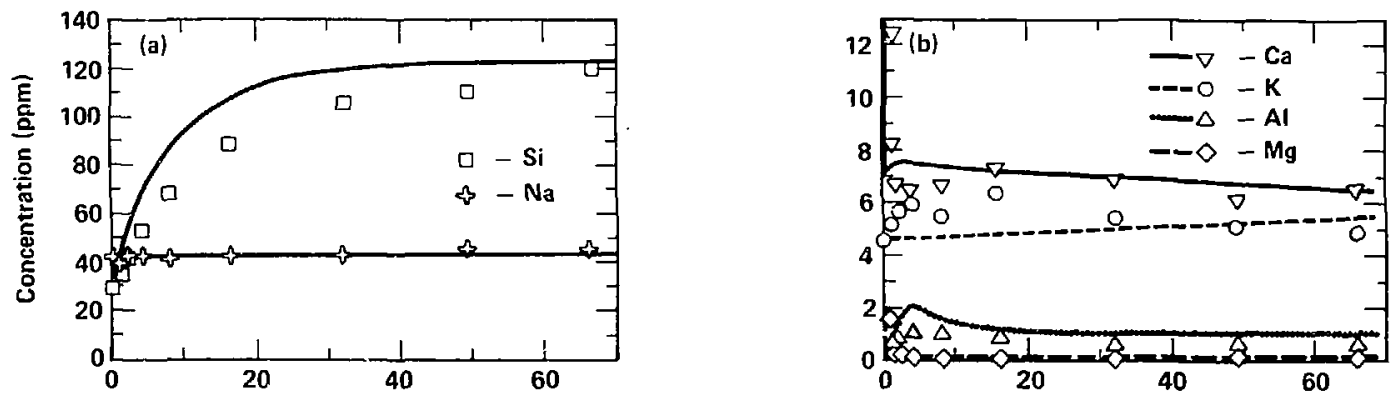

Time (days)

Fig. 1. a) Si and Na concentrations for Topopah Spring tuff reacted with J-13 water at $150^{\circ} \mathrm{C}$.

b) $\mathrm{Ca}, \mathrm{K}, \mathrm{Al}$ and $\mathrm{Mg}$ concentrations for Topopah Spring tuff reacted with $\mathrm{J}-13$ water at $150^{\circ} \mathrm{C}$. Lines show calculated reaction path model concentrations.
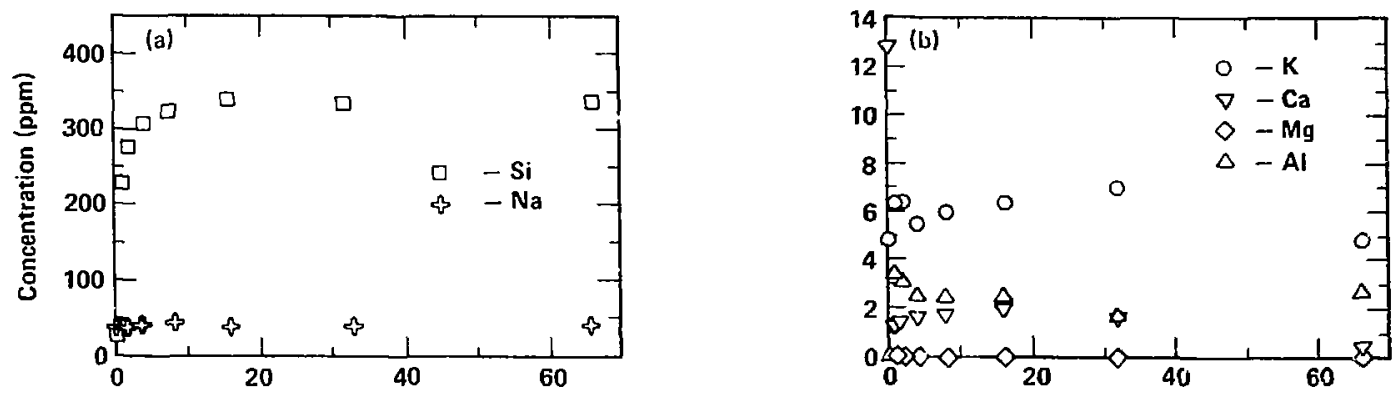

Time (days)

Fig. 2. a) Si and Na concentrations for Topopah Spring tuff reacted with $\mathrm{J}-13$ water at $250^{\circ} \mathrm{C}$.

b) $\mathrm{Ca}, \mathrm{K}, \mathrm{Al}$ and $\mathrm{Mg}$ concentrations for Topopah Spring tuff reacted with $\mathrm{J}-13$ water at $250^{\circ} \mathrm{C}$. 


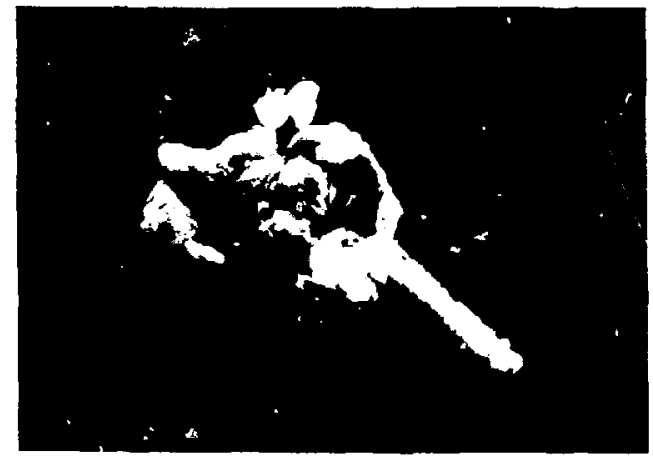

(a)

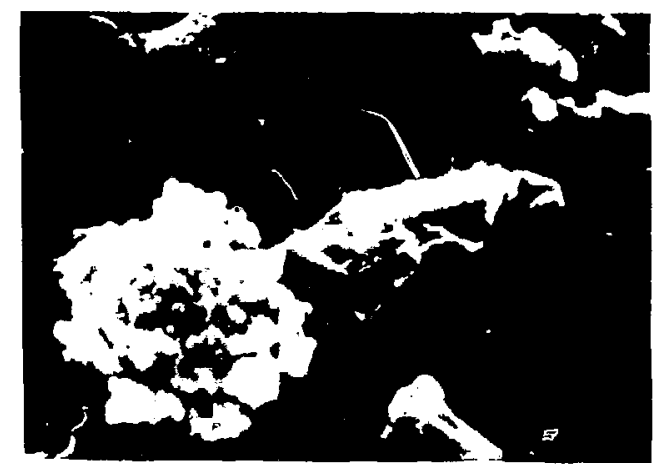

(c)

$$
1 \mu L
$$

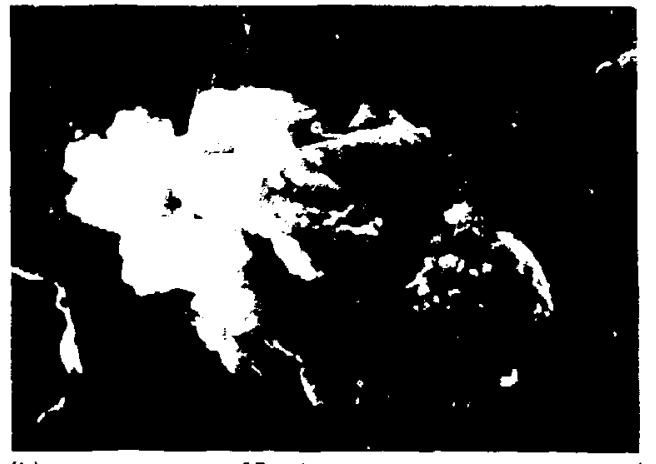

(b)

$$
10 \mu
$$

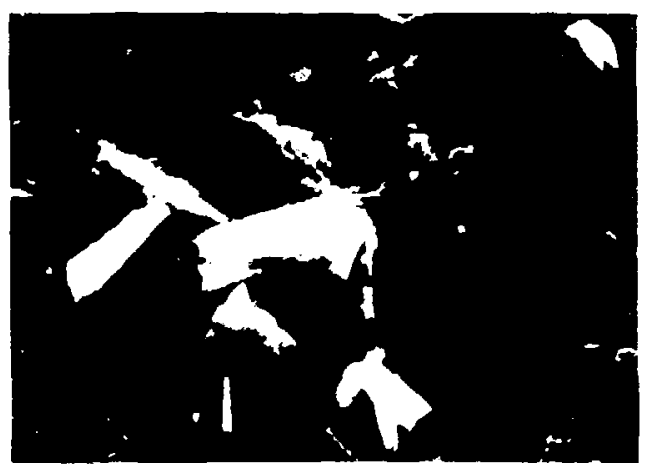

(d)

$10 \mu$

Fig. 3. a) $\mathrm{Mg}$ - \& Fe-rich clay produced in $150^{\circ}$ experiment. b) lllite produced in 150 C experiment. c) Gibbsite and illite produced in 150 C experiment. d) Relict (currently dissolving) calcite produced in the $150^{\circ} \mathrm{C}$ experiment. 


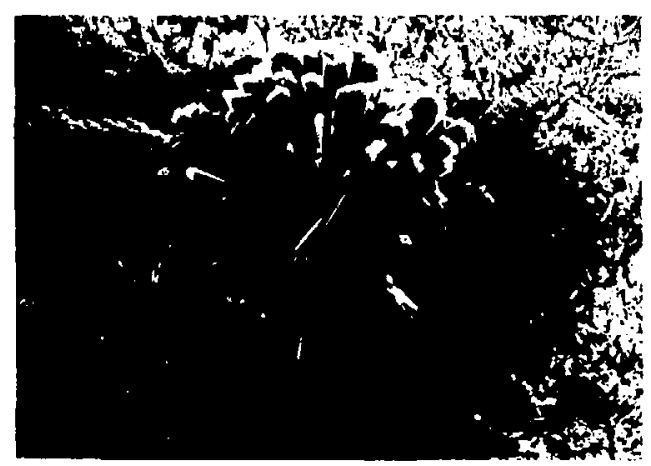

(a)

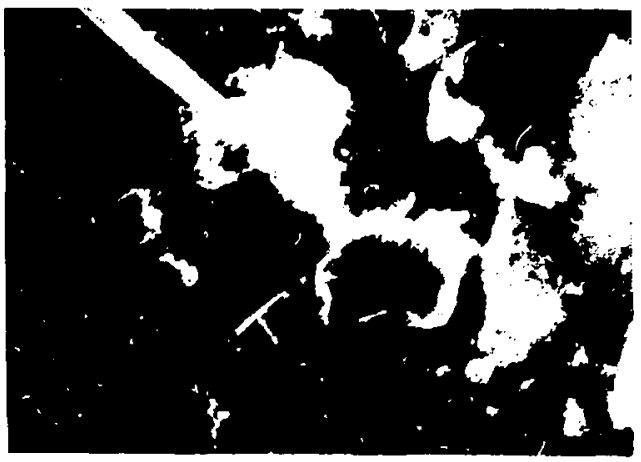

(c)

$10 \mu$
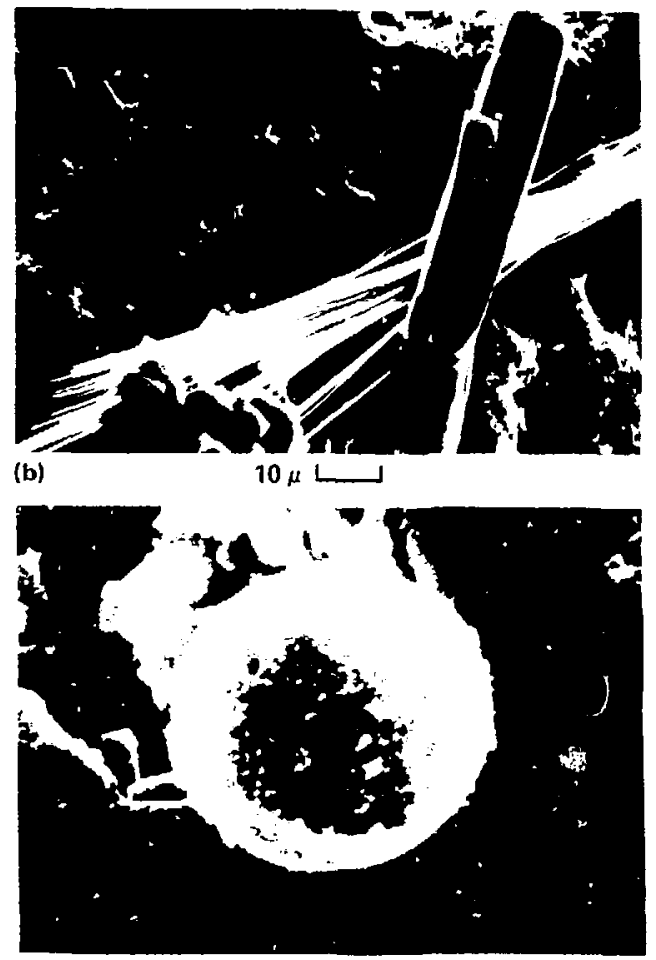

(d)

$10 \mu$

Fig. 4. a) Dachiardite rosette produced in the $250 \mathrm{C}$ experiment. b) Coexisting prismatic dachiardite and mordenite penetrating a dachiardite rosette in the $25 \mathrm{G}^{\circ} \mathrm{C}$ experiment. c) Ca-rich clay on dachiardite in the $250^{\circ} \mathrm{C}$ experiment. d) Cristobalite produced in the $250^{\circ} \mathrm{C}$ experiment. 